\title{
Phases of aeolian accumulation on the Vistula Spit (Southern Baltic Sea) in the light of TL dating and analysis of a digital elevation model
}

\author{
Stanisław FEDOROWICZ, Paweł ZIELIŃSKI, \\ Grażyna WYSIECKA and Beata HOŁUB
}

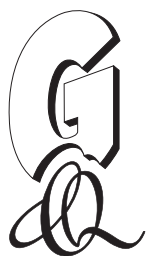

\begin{abstract}
Fedorowicz S., Zieliński P., Wysiecka G. and Hołub B. (2012) - Phases of aeolian accumulation on the Vistula Spit (Southern Baltic Sea) in the light of TL dating and analysis of a digital elevation model. Geol. Quart., 56 (2): 345-352, doi: 10.7306/gq.1026

The genesis of the Vistula Spit (Southern Baltic Sea) in the Postlitorina period is regarded as occurring by gradual addition of successive dune ridges along the entire length of the form. Based on the degree of soil profile development and radiocarbon dating of organic sediments three main stages of aeolian processes are usually recognized. GIS analysis of a digital elevation model (DEM) and thermoluminescence dating of dune sand supports the model of progressive development of dune ridges, and has identified four periods of intense aeolian activity. These were established 5860-5400, 1930-1610, 1200-900 years ago from the present, and from 500 years ago.
\end{abstract}

Stanistaw Fedorowicz and Grażyna Wysiecka, Department of Geomorphology and Quaternary Geology, Gdańsk University, Bażyńskiego 4,80-952 Gdańsk, Poland,e-mails: geosf@ug.gda.pl,geogw@ug.gda.pl; Pawet Zieliński and Beata Hołub, Department of Geoekology and Paleogeography, Maria Curie-Sklodowska University, Kraśnicka 2cd, 20-718Lublin, Poland, e-mails:pziel@umcs.pl, beata.holub@gmail.com (received: September 22, 2011; accepted: March 26, 2012; first published online: June 12, 2012).

Key words: Southern Baltic, Vistula Spit, Holocene, dune ridges, TL dating, DEM.

\section{INTRODUCTION}

The Southern Baltic seashore is characterized by a wave-eroded moraine plateau forming cliffed coasts alternating with spits (formed as a result of both marine and aeolian accumulation) that cut off bays and coastal lowlands (Rosa, 1963; Augustowski, 1972; Borówka, 1990; Tomczak, 1995a, b). Within this, the southern coast of Gdańsk Bay comprises one of the longest spits in the Baltic Sea. The Vistula Spit is a zone of intensive aeolian accumulation, the width of which ranges from $300 \mathrm{~m}$ near Gdańsk and Sopot to $3 \mathrm{~km}$ near Stegna. Its length is about $115 \mathrm{~km}$ (out of which $75 \mathrm{~km}$ lies in Polish territory; Fig. 1). Its western part adjoins the Vistula River delta, and its eastern part has the character of a peninsula separating the Vistula Lagoon from Gdańsk Bay. There are two opposing views about the origin of the spit (Fedorowicz et al., 2009). The first suggests that the spit accumulated by processes transporting material from two opposing directions (Klautzsch, 1919; Beurlen, 1933), while the second involves gradual addition of successive dune ridges along its whole length (Rosa, 1963;
Mojski et al., 1995; Tomczak, 1995a, b; Uścinowicz, 2003). A second problem is the age of accumulation processes, and especially the beginning of spit development. This is determined as during the final stage of the Litorina transgression at $6300 \mathrm{BP}-$ Middle Atlantic (Rosa and Wypych, 1980; Tomczak, 1995b) or at the Postlitorina period in the Middle Subboreal (Tomczak et al., 1989; Musielak, 1980). There is general agreement following Klautzsch (1919) that successive dune ridges were formed in phases. Geomorphological survey, supported by radiocarbon dating, has indicated three phases: 3920-3160 BP, 1210-1060 BP and from $900 \mathrm{BP}$ to present (Tomczak et al., 1989; Tomczak, 1995a, b). Taking into account climate changes, i.e. the cooling periods of Little Ice Age (LIA) type (McDermott et al., 2001) and oscillations of water level in the Baltic Sea (Rosa, 1987; Tomczak, 1995a; Uścinowicz, 2003; Rotnicki, 2009) in the later Holocene, considering radiocarbon dates (Tomczak, 1990), three series of TL dates (Fedorowicz et al., 2009) and also optically stimulated luminescence (OSL) ages of generation foredunes in the Świna Barrier (Reimann et al., 2011) and aeolian accumulation within the coastal dunes on the Jutland Peninsula (Murray and Clemmensen, 2001; 


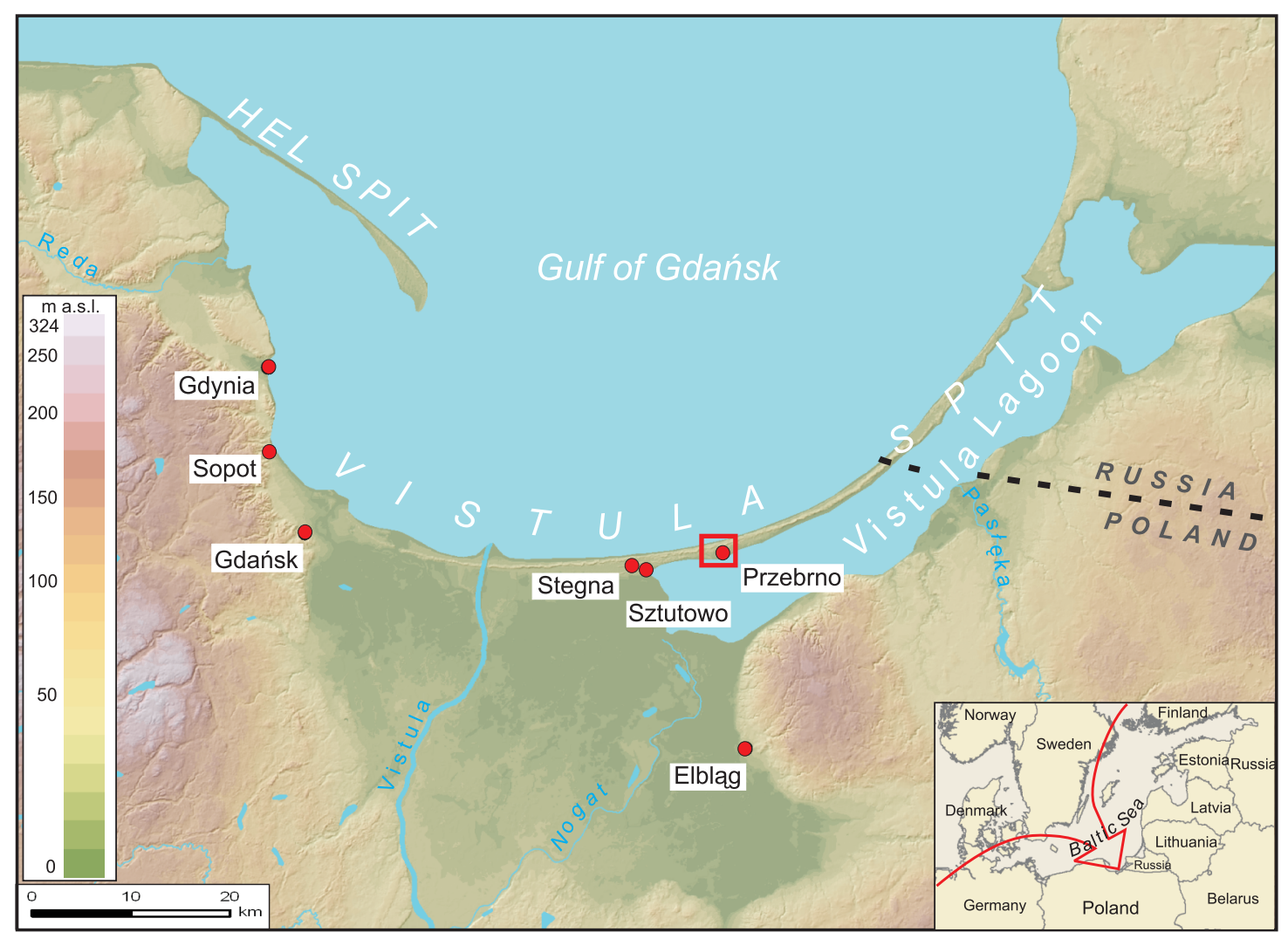

Fig. 1. Location of the Przebrno profile shown on relief map

The red arrow indicates the location of mainly figure

Clemmensen et al., 2009), as many as five aeolian phases have been distinguished in the later Holocene.

In this context, we have carried out detailed dating of aeolian sands in successive cross-sections of the Vistula Spit to constrain the number and age of aeolian phases in which individual dune ridges were formed on the Vistula Spit.

\section{METHODS}

The aims of this project need use of advanced analytical methods (as in Osadczuk, 2004). Firstly topographic maps at a scale of 1:10 000 (sheet N-34-51-D-c-4) were calibrated, and then their hypsometric content was digitized. From this, a digital elevation model was created. It functioned as an input layer in further analytical operations, and from it were derived primary topographic attributes, such as land slope, aspect and curvature. A geological layer (vectorized content of the Detailed Geological Map of Poland at a scale of 1:50 000, Krynica Morska sheet, Makowska, 1987) and soil layer (vectorized content of the Soil-Habitat Map..., 1969) were also included in the analysis. Successive dune ridges can be indicated by the degree of soil podsolization (Keilhack, 1912). Based on this, the extents of white, yellow and brown dunes were determined that enabled us to delineate two research profiles perpendicular to the spit (Fig. 2).

Two cross-sections through the spit (Fig. 3) were compiled based on twelve a hand auger-holes (Eijkelkamp, Netherlands). Two or three samples at different depths were taken from each auger-hole, at up to 5 metres from the dune surface. In total, 29 samples were taken from the profiles for TL dating. At first sample moisture was measured. The dose rate $\left(\mathrm{d}_{\mathrm{r}}\right)$ was determined for a dried sample with use of the MAZAR-95 gamma spectrometer. The concentrations of ${ }^{226} \mathrm{Ra},{ }^{232} \mathrm{Th},{ }^{40} \mathrm{~K}$ in dry mass were measured. One sample was measured 20 times; each measurement lasted 2000 s. The concentrations of radionuclides were converted into dose rates for alpha, beta and gamma radiation. The dose rate was calculated with corrections for deposit moisture, dose of cosmic radiation, grain size, and time of etching with hydrogen fluoride (HF; Aitken and Xie, 1985; Adamiec and Aitken, 1998). Uncertainty of dose rate determination was about 3\% (Poręba and Fedorowicz, 2005). The measurement of equivalent dose $\left(\mathrm{d}_{\mathrm{e}}\right)$ was preceded by preliminary treatment. The $80-100 \mu \mathrm{m}$ quartz grain fraction, separated by sieving, was treated with $10 \% \mathrm{HCl}$ for twenty-four hours, and then with $2 \% \mathrm{NaOH}$ for twenty-four hours. Then grains were etched with $40 \% \mathrm{HF}$ for 45 minutes (Bluszcz, 2000). After each treatment a sample was washed with distilled water. The equivalent dose $\left(d_{e}\right)$ was measured by the TL multi- 

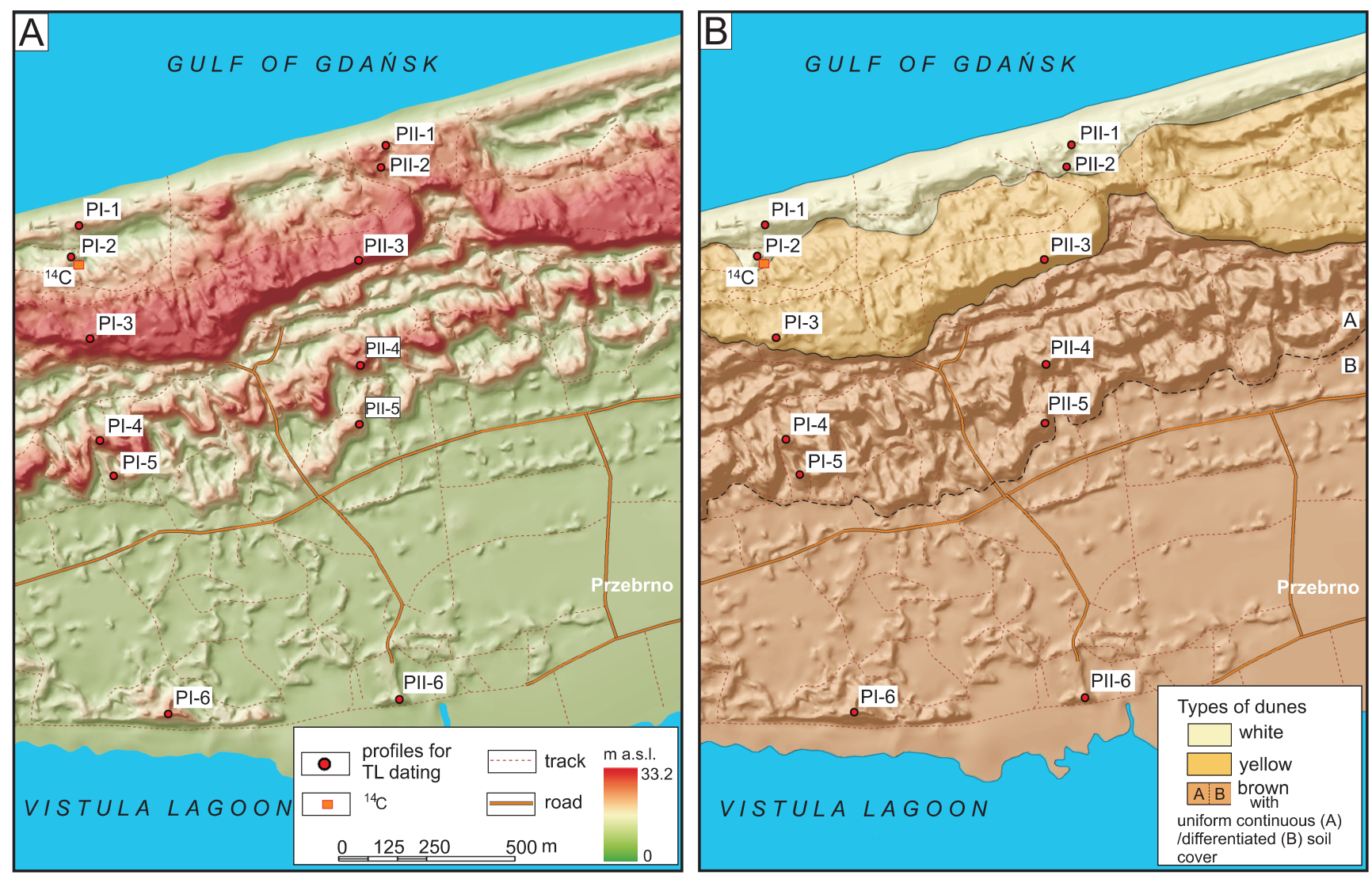

Fig. 2. Location of research sites shown on: A - digital elevation model near Przebrno; B - dune generations, which were marked on the basis of the Soil-Habitat Map.... (1969)

ple-aliquot regeneration technique (Wintle and Prószyńska, 1983), according to the description published by Fedorowicz (2006). The glow curves were recorded using a TL reader-analyser of $R A^{\prime} 94$ type (with an EMI $9789 Q A$ photomultiplier) linked with an IBM computer. A sample was heated in argon atmosphere to $400^{\circ} \mathrm{C}$ with a heating rate of $8^{\circ} \mathrm{C} / \mathrm{s}$. The $R A^{\prime} 94$ reader-analyser was used with a $B G-28$ optical filter (Berger et al., 1992). The peak analysed occurred at about $250^{\circ} \mathrm{C}$. The plateau occurred between 230 and $280^{\circ} \mathrm{C}$. Grain sensitivity was tested by additional measurements.

\section{RESULTS}

Analysis of the digital elevation model indicates that $10.1 \%$ of the area examined is covered by white dunes, $16.1 \%$ by yellow, and $73.9 \%$ by the brown ${ }^{1}$ dunes (Fig. 2). The white dunes form the ridge of the fore-dune reaching a height of slightly over $10 \mathrm{~m}$, being undercut by coastal abrasion in places. Considerable lows to $3.75 \mathrm{~m}$ a.s.l. occur in this ridge, and extend, to the south where they from wind-blown depressions up to $600 \mathrm{~m}$ long and $150 \mathrm{~m}$ wide. A second discontinuous ridge occurs between these depressions. It is composed of forms up to $140 \mathrm{~m}$ long and $15 \mathrm{~m}$ high. In this zone, 6 samples from white dunes and 4 samples from wind-blown depressions were taken (Table 1). The TL ages obtained for white dunes range from 0.3 \pm 0.1 to $0.5 \pm 0.1 \mathrm{ka}$, and those for depressions range from 0.9 \pm 0.1 to $1.2 \pm 0.1 \mathrm{ka}$. The TL ages were compared with the results of radiocarbon dating of sub-fossil organogenic layers. Two radiocarbon dates were obtained: cal. $295 \pm 125 \mathrm{BP}$ (Gd-30231) and cal. $500 \pm 110$ BP (Gd-30232) (Fig. 3). The highest train of dunes forms the zone (70-410 m wide) of yellow dunes. These are arch and parabolic forms of different size often occurring in the foreland of the wind-blown depressions described above. The largest of these reach a height of $30 \mathrm{~m}$ in the front part, a length of $900 \mathrm{~m}$ along the ridge, and their arm-span is up to $400 \mathrm{~m}$. Based on dating of 5 samples (PI-3, PII-3), the age of these dunes was determined at $1.61 \pm 0.2-1.85$ \pm 0.2 ka (Fig. 3 and Table 1). The next zone of brown dunes is the widest one (1050-1450 m) in the area examined. It is composed of three dune trains: 1) a continuous dune train composed

\footnotetext{
${ }^{1}$ The dune generations are characterized by the degree of soil development. The brown dunes have complete soil profile developed, the yellow ones are covered by initial soils, and white dunes are active forms without soil cover.
} 
Luminescence dates of samples from Przebrno

\begin{tabular}{|c|c|c|c|c|c|c|c|c|c|c|c|}
\hline \multirow{2}{*}{$\begin{array}{l}\text { No. of } \\
\text { drilling }\end{array}$} & \multirow{2}{*}{ Dune ridges } & \multirow{2}{*}{$\begin{array}{c}\text { Depth } \\
{[\mathrm{m}]}\end{array}$} & \multirow{2}{*}{$\begin{array}{l}\text { No. Lab. } \\
\text { UG }\end{array}$} & \multicolumn{4}{|c|}{ Radionuclide concentration $\left(\mathrm{Bq} \mathrm{kg}^{-1}\right)$} & \multirow{2}{*}{$\begin{array}{c}\text { Water content } \\
{[\%]}\end{array}$} & \multirow{2}{*}{$\begin{array}{c}\text { Dose rate } d_{r} \\
{[\mathrm{~Gy} / \mathrm{ka}]}\end{array}$} & \multirow{2}{*}{$\begin{array}{l}\text { Equivalent } \\
\text { dose } d_{e}[G y]\end{array}$} & \multirow{2}{*}{$\begin{array}{c}\text { TL age } \\
{[\mathrm{ka}]}\end{array}$} \\
\hline & & & & ${ }^{226} \mathrm{Ra}$ & ${ }^{232} \mathrm{Th}$ & ${ }^{40} \mathrm{~K}$ & $d_{c}$ & & & & \\
\hline \multirow{3}{*}{ PI-1 } & white & 1.00 & 6071 & $20.8 \pm 1.1$ & $23.6 \pm 0.6$ & $452 \pm 6$ & 0.14 & $4 \pm 4$ & $2.42 \pm 0.10$ & $1.21 \pm 0.25$ & $0.50 \pm 0.10$ \\
\hline & white & 2.00 & 6072 & $20.4 \pm 1.1$ & $22.8 \pm 0.6$ & $449 \pm 6$ & 0.11 & $5 \pm 4$ & $2.37 \pm 0.09$ & $1.19 \pm 0.25$ & $0.51 \pm 0.11$ \\
\hline & white & 4.00 & 6073 & $21.0 \pm 1.1$ & $23.0 \pm 0.6$ & $450 \pm 6$ & 0.06 & $4 \pm 4$ & $2.40 \pm 0.11$ & $1.20 \pm 0.25$ & $0.50 \pm 0.12$ \\
\hline \multirow{2}{*}{ PI-2 } & white/yellow & 2.00 & 6074 & $20.4 \pm 1.4$ & $22.2 \pm 0.7$ & $440 \pm 6$ & 0.11 & $4 \pm 4$ & $2.29 \pm 0.10$ & $2.30 \pm 0.24$ & $1.03 \pm 0.12$ \\
\hline & white/yellow & 3.80 & 6075 & $20.8 \pm 1.2$ & $23.0 \pm 0.7$ & $445 \pm 7$ & 0.06 & $4 \pm 4$ & $2.37 \pm 0.11$ & $2.37 \pm 0.24$ & $1.03 \pm 0.10$ \\
\hline \multirow{3}{*}{ PI-3 } & yellow & 2.00 & 6076 & $24.0 \pm 1.1$ & $26.0 \pm 0.6$ & $475 \pm 7$ & 0.11 & $4 \pm 4$ & $2.63 \pm 0.12$ & $4.81 \pm 0.48$ & $1.83 \pm 0.21$ \\
\hline & yellow & 4.00 & 6077 & $21.7 \pm 0.6$ & $24.7 \pm 0.6$ & $467 \pm 5$ & 0.06 & $4 \pm 4$ & $2.65 \pm 0.11$ & $4.90 \pm 0.49$ & $1.85 \pm 0.20$ \\
\hline & yellow & 5.00 & 6078 & $20.8 \pm 0.6$ & $24.4 \pm 0.7$ & $453 \pm 6$ & 0.04 & $4 \pm 4$ & $2.62 \pm 0.10$ & $4.72 \pm 0.50$ & $1.80 \pm 0.22$ \\
\hline \multirow{2}{*}{ PI-4 } & brown & 2.00 & 6079 & $21.0 \pm 0.6$ & $23.8 \pm 0.6$ & $455 \pm 7$ & 0.11 & $4 \pm 4$ & $2.57 \pm 0.10$ & $4.65 \pm 0.47$ & $1.81 \pm 0.21$ \\
\hline & brown & 4.00 & 6080 & $21.8 \pm 1.1$ & $25.0 \pm 0.6$ & $460 \pm 6$ & 0.11 & $4 \pm 4$ & $2.66 \pm 0.11$ & $4.95 \pm 0.50$ & $1.86 \pm 0.22$ \\
\hline \multirow{2}{*}{ PI-5 } & brown & 2.00 & 6081 & $20.8 \pm 1.2$ & $22.9 \pm 0.7$ & $458 \pm 6$ & 0.11 & $4 \pm 4$ & $2.58 \pm 0.11$ & $4.72 \pm 0.47$ & $1.83 \pm 0.20$ \\
\hline & brown & 4.05 & 6082 & $20.9 \pm 1.0$ & $23.6 \pm 0.7$ & $459 \pm 6$ & 0.06 & $4 \pm 4$ & $2.58 \pm 0.10$ & $4.67 \pm 0.47$ & $1.81 \pm 0.20$ \\
\hline \multirow{3}{*}{ PI-6 } & brown & 1.50 & 6083 & $25.8 \pm 1.0$ & $27.5 \pm 0.4$ & $548 \pm 5$ & 0.12 & $5 \pm 4$ & $2.88 \pm 0.11$ & $15.55 \pm 1.6$ & $5.40 \pm 0.52$ \\
\hline & brown & 4.05 & 6084 & $21.7 \pm 1.3$ & $24.0 \pm 0.7$ & $547 \pm 5$ & 0.06 & $4 \pm 4$ & $2.83 \pm 0.12$ & $15.71 \pm 1.6$ & $5.55 \pm 0.62$ \\
\hline & brown & 4.40 & 6085 & $28.3 \pm 1.1$ & $27.4 \pm 0.5$ & $523 \pm 5$ & 0.05 & $4 \pm 4$ & $2.79 \pm 0.11$ & $15.60 \pm 1.6$ & $5.59 \pm 0.63$ \\
\hline \multirow{3}{*}{ PII-1 } & white & 2.00 & 6086 & $21.0 \pm 1.2$ & $23.0 \pm 0.6$ & $250 \pm 6$ & 0.11 & $4 \pm 4$ & $2.39 \pm 0.10$ & $0.7 \pm 0.35$ & $0.30 \pm 0.12$ \\
\hline & white & 4.00 & 6087 & $21.8 \pm 1.1$ & $22.6 \pm 0.6$ & $255 \pm 6$ & 0.06 & $4 \pm 4$ & $2.42 \pm 0.09$ & $1.21 \pm 0.25$ & $0.52 \pm 0.11$ \\
\hline & white & 5.00 & 6088 & $20.9 \pm 1.1$ & $23.6 \pm 0.6$ & $259 \pm 7$ & 0.04 & $4 \pm 4$ & $2.43 \pm 0.10$ & $1.22 \pm 0.25$ & $0.52 \pm 0.12$ \\
\hline \multirow{2}{*}{ PII-2 } & white/yellow & 2.00 & 6089 & $21.7 \pm 1.2$ & $25.5 \pm 0.7$ & $470 \pm 7$ & 0.11 & $4 \pm 4$ & $2.42 \pm 0.11$ & $2.18 \pm 0.24$ & $0.93 \pm 0.11$ \\
\hline & white/yellow & 4.00 & 6090 & $20.0 \pm 1.1$ & $21.4 \pm 0.6$ & $454 \pm 6$ & 0.06 & $4 \pm 4$ & $2.32 \pm 0.10$ & $2.78 \pm 0.28$ & $1.20 \pm 0.10$ \\
\hline \multirow{2}{*}{ PII-3 } & yellow & 2.00 & 6091 & $23.8 \pm 0.7$ & $25.9 \pm 0.7$ & $479 \pm 7$ & 0.11 & $5 \pm 4$ & $2.59 \pm 0.10$ & $4.17 \pm 0.42$ & $1.61 \pm 0.22$ \\
\hline & yellow & 4.00 & 6092 & $23.9 \pm 0.8$ & $25.8 \pm 0.6$ & $486 \pm 7$ & 0.06 & $4 \pm 4$ & $2.66 \pm 0.11$ & $4.92 \pm 0.50$ & $1.85 \pm 0.20$ \\
\hline \multirow{2}{*}{ PII-4 } & brown & 2.00 & 6093 & $20.9 \pm 0.7$ & $23.6 \pm 0.7$ & $458 \pm 7$ & 0.11 & $4 \pm 4$ & $2.60 \pm 0.10$ & $4.21 \pm 0.44$ & $1.62 \pm 0.22$ \\
\hline & brown & 4.00 & 6094 & $21.0 \pm 0.7$ & $23.0 \pm 0.6$ & $450 \pm 6$ & 0.06 & $4 \pm 4$ & $2.57 \pm 0.10$ & $4.65 \pm 0.48$ & $1.81 \pm 0.21$ \\
\hline \multirow{3}{*}{ PII-5 } & brown & 2.00 & 6095 & $21.4 \pm 0.7$ & $24.0 \pm 0.7$ & $450 \pm 6$ & 0.11 & $4 \pm 4$ & $2.55 \pm 0.11$ & $4.11 \pm 0.42$ & $1.61 \pm 0.20$ \\
\hline & brown & 4.00 & 6096 & $20.9 \pm 0.7$ & $25.2 \pm 0.7$ & $461 \pm 6$ & 0.06 & $4 \pm 4$ & $2.63 \pm 0.11$ & $4.66 \pm 0.50$ & $1.77 \pm 0.21$ \\
\hline & brown & 5.00 & 6097 & $21.0 \pm 0.7$ & $25.5 \pm 0.7$ & $459 \pm 7$ & 0.05 & $4 \pm 4$ & $2.63 \pm 0.10$ & $5.08 \pm 0.52$ & $1.93 \pm 0.32$ \\
\hline \multirow{2}{*}{ PII-6 } & brown & 2.00 & 6098 & $19.2 \pm 1.4$ & $26.6 \pm 0.7$ & $540 \pm 6$ & 0.11 & $4 \pm 4$ & $2.87 \pm 0.12$ & $15.67 \pm 1.6$ & $5.46 \pm 0.60$ \\
\hline & brown & 4.00 & 6099 & $20.8 \pm 1.3$ & $27.1 \pm 0.6$ & $528 \pm 7$ & 0.06 & $4 \pm 4$ & $2.79 \pm 0.12$ & $16.35 \pm 1.7$ & $5.86 \pm 0.62$ \\
\hline
\end{tabular}

of medium and small arch and parabolic forms up to $15 \mathrm{~m}$ high and 200-300 m long; morphologically this train distinctly resembles yellow dunes but the soil cover and hypsometric conditions are different; 2) a discontinuous train composed of single small arch dunes up to $5 \mathrm{~m}$ high and $200 \mathrm{~m}$ long, separated by small (50-150 m long) waterlogged wind-blown depressions, and 3) ridge dunes about $10 \mathrm{~m}$ high and up to $250 \mathrm{~m}$ long occurring near the shore of the Vistula Lagoon and separated by larger wind-blown depressions, that are up to $200 \mathrm{~m}$ long and $300 \mathrm{~m}$ wide. The TL ages of 14 samples occur in two intervals from $1.62 \pm 0.22$ to $1.93 \pm 0.32 \mathrm{ka}$ and from $5.40 \pm 0.52$ to $5.86 \pm 0.62 \mathrm{ka}$ (Fig. 3 and Table 1).

\section{DISCUSSION OF RESULTS}

The analysis of a DEM (digital elevation model) and a DTM (digital terrain model) shows the existence of three dune zones (Fig. 2). Dunes occurring in each separate zone are similar in terms of hypsometry and morphology, so probably have a common origin. This is especially clear in the case of the yel- low dunes - mostly arch and parabolic forms of considerable size and concentration, with initial soils. The zone of brown dunes is less uniform. Podzolic soils form a continuous cover on the train adjacent to the yellow dune zone. In two other trains podzolic soils occur only on dunes whereas peat and hydrogenic soils are found in the inter-dune depressions. The different arrangement and morphology of forms indicate that the zone is not uniform. We tentatively distinguish two subzones within the zone of brown dunes. The first is characterized by a dense pattern of dunes, which are mostly arch forms. Scattered ridge dunes dominate in the second subzone. It is more difficult to delineate a clear boundary between the white and yellow dunes due to the occurrence of the second discontinuous ridge of white dunes, which is often situated within the wind-blown depressions supplying the yellow dunes (Fig. 2). Therefore, it can be assumed that this dune ridge is a transitional unit between the white and yellow dunes as observed by Fedorowicz et al. (2009), and also in papers describing the development of the Vistula Spit (Tomczak, 1990). Two generations of white dunes were also described by Osadczuk (2004) in the Świna Barrier. 
30 [m a.s.I.]

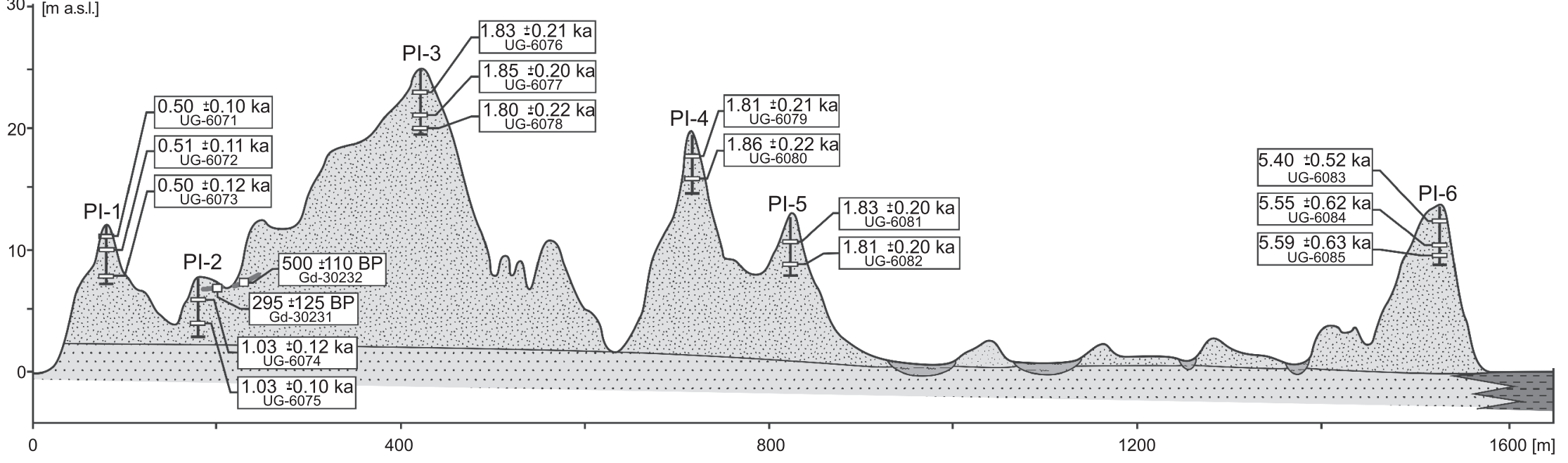

\section{$\mathrm{N}$}

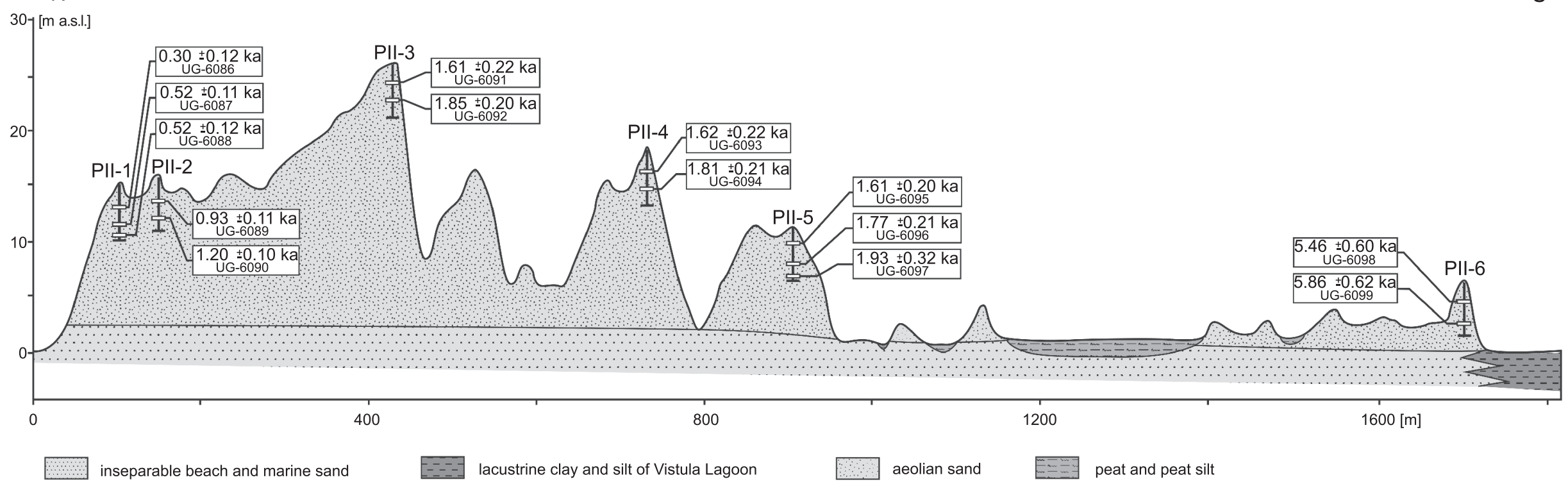

Fig. 3. Simplified geological profiles through the Vistula Spit near Przebrno and results of TL dating 
This matter is elucidated by TL dating of separate dune trains. The results obtained in the white, yellow and transitional dune zones clearly indicate their different ages, and are consistent with distinguishing a transitional zone between white and yellow dunes. The dates from the brown dunes form two groups. The first, distinctly younger, with dates ranging from 1.62 to $1.93 \mathrm{ka}$, in terms of age resembles the yellow dunes. Based on dating of dunes in Stegna, Fedorowicz et al. (2009) distinguish also a transitional zone between yellow and brown dunes but the dates obtained, ranging from 4.24 to $5.63 \mathrm{ka}$, correspond better to the age of brown dunes. Therefore, the younger subzone of brown dunes discussed above cannot be identified with this transitional zone of yellow-brown dunes. It seems reasonable to include the continuous train of brown dunes in the zone of yellow dunes based on their similar morphology, dune orientation, continuous soil cover and TL age. They differ in hypsometric conditions and degree of pedogenesis development. This problem needs further investigation. Similarly distributed ages indicating distinct separation of the OSL dates were obtained by Reimann et al. (2011) from brown dunes from the Świna Barrier.

The TL ages obtained are classified into four distinct periods/phases of intensified aeolian accumulation (Fig. 4). The first of these is indicated by the dating results of the oldest train

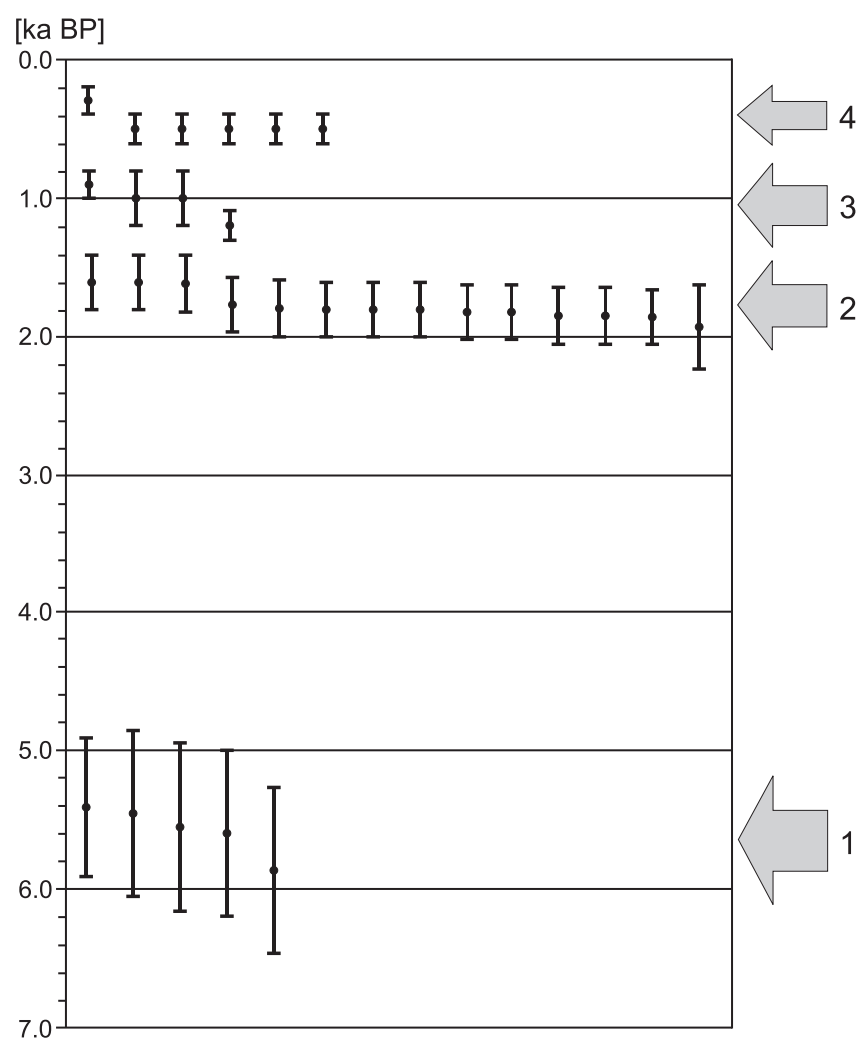

Fig. 4. Phases of intensification of aeolian processes on the basis of TL dates of brown dunes adjacent to the Vistula Lagoon. The average TL age corresponding to this phase is $5.57 \pm 0.53 \mathrm{ka}$, and the whole period is estimated at over 400 years. These results differ considerably from the formerly determined time of the beginning and duration of the first phase of dune accumulation on the Vistula Spit. Based on the results of radiocarbon dating of the bottom peats in the inter-dune depressions, Tomczak (1990) estimated the end of the first phase of the Spit development at 3920-3160 BP (cal. $3380-4360{ }^{14} \mathrm{C} \mathrm{BP}^{2}$ ). She also suggested that marine regression initiated this phase i.e. after the Litorina transgression; so the beginning of aeolian transformation of beach ridges occurred about $5000 \mathrm{BP}$. Analogous radiocarbon dating on the Świna Spit (western part of Polish coast) indicates an age of $4810 \mathrm{BP}$ (cal. $5585{ }^{14} \mathrm{C}$ BP; Prusinkiewicz and Noryśkiewicz, 1966) and on the Curonian Spit (Lithuanian coast) of 4630 BP (Gaigalas et al., 1989). These results better correspond to those obtained by us. The increasing number of luminescence dates seems to confirm the existence of a phase of intensified aeolian activity in the coastal dune zone at the turn of the Atlantic and Subboreal periods (Gaigalas et al., 1989; Borówka, 1990, 2001; Murray and Clemmensen, 2001; Osadczuk, 2004; Moe et al., 2005; Molodkov and Bitinas, 2006; Clemmensen et al., 2009; Reimann et al., 2011). This phase of aeolian accumulation on the Vistula Spit was dated at 7.28-5.12 TL ka by Fedorowicz et al. (2009). In the light of OSL dating from the Świna Barrier, aeolian accumulation of the first generation of brown dunes began at $6.62 \pm 0.42 \mathrm{ka}$ on the Uznam Spit and at $5.39 \pm 0.37 \mathrm{ka}$ on the Wolin Spit, while its termination is expressed by a date of $2.45 \pm 0.15 \mathrm{ka}$ (Reimann et al., 2011). On the Jutland Peninsula, however, the oldest (4) phase of aeolian sand accumulation occurred at 4.6-4.3 ka (Murray and Clemmensen, 2001; Clemmensen et al., 2009).

The second phase of intensified aeolian processes on the Vistula Spit is represented by the dates ranging from 1.93 to $1.61 \mathrm{ka}$. They correspond to the end of accumulation of yellow dunes determined by Tomczak (1990) at 1210-1060 BP. However, yellow dunes on the Świna Spit were dated by Prusinkiewicz and Noryśkiewicz (1966) at the 15-17th century. However, the OSL dates of $1.72 \pm 0.12 \mathrm{ka}$ and 1.65 \pm 0.11 ka obtained from the second generation of brown dunes by Reimann et al. (2011) correspond well with the results described here. The bottom parts of dunes on the Curonian Spit were OSL dated by Bitinas (2004) at cal. $1500 \pm 100 \mathrm{a}$. Moe et al. (2005) obtained a very similar AMS (Accelerator Mass Spectrometry Radiocarbon Dating) date (cal. $1900 \pm 40{ }^{14} \mathrm{C}$ BP) from subfossil soil covering the aeolian deposits. A slightly younger age $(1.2 \pm 0.1 \mathrm{ka})$ was obtained for dune sands on the Curonian Spit by Molodkov and Bitinas (2006). Fedorowicz et al. (2009) obtained a broad spectrum of TL dates (6.0-1.53 ka) from the Stegna profile (Vistula Spit). Clemmensen et al. (2009) determined the age of the dune-forming phase denoted as no. 2 on the Jutland Peninsula at 2.0-1.59 ka.

\footnotetext{
${ }^{2}$ Dates calibrated on the basis of tables by Reimer et al. (2004) included in Walanus and Goslar (2009).
} 
The third phase of aeolian processes took place between 1.2 and $0.9 \mathrm{ka}$. It resulted in the formation of the discontinuous dune ridge (between the yellow dunes and the foredune) and the wind-blown depressions, and probably in the building of the northern slopes of the yellow dunes. According to Tomczak (1990), a marine ingression on the Vistula delta in the Sztutow region occurred at that time. Similar observations were conducted by Rotnicki (2009) on the Gardno-Leba Lowland indicating a rapid increase in Baltic sea level between 1.8 and $1.1 \mathrm{ka} \mathrm{BP}$ (3.4 mm/year), followed by a stable high water level until $0.7 \mathrm{ka}$ BP. The rise in sea level caused the undercutting of beach ridges that probably narrowed the beach, which was the natural alimentation area for dunes on the spit (Borówka, 1999). Therefore, the material supply for dune formation was considerably reduced. However, the deposits of similar age occur on the Lithuanian coast (Molodkov and Bitinas, 2006), and on the Danish coast where the dune-forming phase denoted as no. 1 is related to this period (Clemmensen et al., 2009). So it seems that the rise in sea level is not a significant impediment to the intensification of dune-forming processes. Borówka (1999) indicates that aeolian deposition in foredunes reaches significant values nowadays, of about $1.5 \mathrm{~m} /$ year, though the rise in sea level is a constant trend. Reimann et al. (2011), however, reconstruct the rate of the yellow dunes' growth at $1.3-1.1 \mathrm{~m} /$ year. One thousand years ago the destruction of beach ridges on the Vistula Spit could have moved a great amount of sand, which was then transported by longshore drift; after storms this sand could have been accessible for aeolian transport. Additionally, the wind-transported material could have originated from the formerly accumulated deposits as is shown by the occurrence of wind-blown depressions between white and yellow dunes.

The youngest phase of intensification of aeolian processes is dated at $0.5-0.3 \mathrm{ka}$. A similar age was obtained for the Stegna profile by Fedorowicz et al. (2009). On the other hand, according to Tomczak (1990) this phase has continued for the last 900 years, with slightly less intense processes from 480 to 340 years ago. This is undoubtedly correct because the processes in the foredune zone are incessantly active though periodically less intense. In the Przebrno profile such weakenings are radiocarbon dated at $295 \pm 125 \mathrm{BP}$ (Gd-30231) and 500 $\pm 110 \mathrm{BP}$ (Gd-30232); these dates are similar to the age range given by Tomczak (1990). Borówka (1990, 2001) described the reactivation of aeolian processes on the Leba Spit at about $500 \mathrm{BP}$, which was influenced by human activity but caused mainly by deteriorating climatic conditions expressed mainly by a decrease in mean temperature and an increase in the number of storms. Similar conclusions about the age and causes of activation of aeolian processes resulted also from the investigations on the Wolin Spit (Reimann et al., 2011), on the Curonian Spit (Bitinas, 2004; Moe et al., 2005) and on the northern coast of Denmark (Aagaard et al., 2007; Clemmensen et al., 2009).

The four phases of aeolian accumulation on the Vistula Spit described have their equivalents on other spits of the Southern
Baltic as well as in the western and northern parts of the Jutland Peninsula (Gaigalas et al., 1989; Borówka, 1990, 2001; Murray and Clemmensen, 2001; Bitinas, 2004; Osadczuk, 2004; Moe et al., 2005; Molodkov and Bitinas, 2006; Aagaard et al., 2007; Clemmensen et al., 2009; Reimann et al., 2011). Comparing the age of these phases with the cooling periods of LIA type (McDermott et al., 2001) it seems that deposition was triggered by such weather conditions. According to Reimann et al. (2011) intensified storms delivered larger amounts of sand material onto the beaches, which was subsequently used in aeolian transport that was accelerated by stronger winds. These phases can also be correlated with relative oscillations of water level in the southern Baltic (Rotnicki, 2009); in general, they correspond with periods of decreased water level. An exception is the second phase, dated by the authors between 1.93 and $1.61 \mathrm{ka}$ (Fig. 4), which corresponds with the Roman Warm Period (RWP; McDermott et al., 2001; Reimann et al., 2011), and also a relative increase in the water level of the Baltic (Rotnicki, 2001). Reimann et al. (2001) interpret the restart of the aeolian transport as due to human activity in the area, mainly deforestation.

\section{FINAL REMARKS}

The data presented are a contribution to the discussion on the origin, age and phases of the formation of the Vistula Spit. They enlarge the collection of absolute dating results obtained for this area. Based on the large set of TL ages, global tendencies and local variation of the processes discussed can be indicated. The authors consider that three facts are worth noting.

Based on the degree of soil cover development, only general information about the age and sequence of formation of the dune ridges distinguished can be obtained. This is most evident within the zone of brown dunes where two dune ridges are distinctly different in terms of age, and one of them in terms of age resembles the yellow dunes. Moreover, we should take into account that stable dunes were/could have been transformed to some extent during the addition of successive dune ridges.

Aeolian processes were activated periodically. In the area examined they were intensified in the following periods: 5860-5400, 1930-1610, 1200-900 and from 500 years ago. This intensification was most probably determined by deterioration of climatic conditions of LIA type, which resulted in a decrease in mean annual air temperature, an increase in the number of storms, and lowering of the water level in the Baltic Sea. The exception was the phase occurring 1930-1610 years ago, which corresponded to a warm period (RWP) and a rise of sea level. So, the intensification of aeolian deposition during this phase should be related to anthropogenic factors.

Acknowledgements. We would like to express our gratitude to the reviewers for kind, valuable and thorough remarks on the submitted manuscript. 


\section{REFERENCES}

AAGAARD T. T., ORFORD J. and MURRAY A. S. (2007) - Environmental controls on coastal dune formation; Skallingen Spit, Denmark. Geomorphology, 83: 29-47.

ADAMIEC G. and AITKEN M. J. (1998) - Dose-rate conversion factors: update. Ancient TL, 16 (2): 37-50.

AITKEN M. J. and XIE J. (1985) - Moisture correction for annual gamma dose. Ancient TL, 8 (2): 6-9.

AUGUSTOWSKI B. (1972) - Niziny Nadmorskie (Pobrzeże Bałtyckie). In: Geomorfologia Polski (ed. R. Galon): 111-128. PWN.

BEURLEN K. (1933) - Die Nehrungen Ostpreussens und ihre Entstehung. Aus der Heimat, 2: 13-17.

BERGER G. W., PILLANS B. J. and PALMER A. S. (1992) - Dating loess up to $800 \mathrm{ka}$ by thermoluminescence. Geology, 20: 403-406.

BITINAS A. (2004) - The age of aeolian deposits in Lithuania (in Lithuanian with English summary). Geologija, 45: 1-5.

BLUSZCZ A. (2000) - Datowanie luminescencyjne osadów czwartorzędowych - teoria, ograniczenia, problem interpretacyjne. Zeszyty Naukowe Politechniki Śląskiej, seria Matematyka-Fizyka, 86. Geochronometria, 17.

BORÓWKA R. K. (1990) - Coastal dunes in Poland. Catena, Supplement, 18: $25-30$.

BORÓWKA R. K. (1999) - Potencjalny transport eoliczny na plażach w okolicach Świnoujścia a tendencje rozwojowe wydm przednich. In: Ewolucja geosystemów nadmorskich południowego Bałtyku (eds. R. K. Borówka, Z. Młynarczyk and A. Wojciechowski): 25-30. Bogucki Wyd. Nauk., Poznań-Szczecin.

BORÓWKA R. K. (2001) - Historia rozwoju wydm Mierzei Łebskiej. In: Przemiany środowiska geograficznego nizin nadmorskich południowego Bałtyku w vistulianie i holocenie (ed. K. Rotnicki): 81-84. Bogucki Wyd. Nauk., Poznań.

CLEMMENSEN L. B., MURRAY A., HEINEMEIER J. and De JONG R. (2009) - The evolution of Holocene coastal dunefields, Jutland, Denmark: a record of climate change over the past 5000 years. Geomorphology, 105: 303-313.

FEDOROWICZ S. (2006) - Metodyczne aspekty luminescencyjnego oznaczania wieku osadów neoplejstoceńskich Europy Środkowej. Wyd. Uniw. Gdańskiego.

FEDOROWICZ S., GOŁEBBIEWSKI R. and WYSIECKA G. (2009) - The age of the dunes of the Vistula Spit in the vicinity of Stegna. Geologija, 52 (3-4): 139-145.

GAIGALAS A., BANIS J. J., GULBINSKAS S. P. and SAWUKIENE N. P. (1989) - Radiouglerodnyy vozrast pogrubiennykh pochv w diunakh Kurskoy kosy. Geokhronologicheskiye i izotopnogeokhimicheskiye issledovaniya v Pribaltikie i Bielorusi. Tezisy VIII izotopnogeokhimicheskogo soveshchaniya pribaltyyskikh respublik i Bielorusskoy SSR. Vilnius: 16-18.

KEILHACK K. (1912) - Die Verlandung der Swinepforte. Jb. Königl.Preuss. Geol. L. A., 32: 209-244.

KLAUTZSCH A. (1919) - Zur Entstehungsgeschichte der Frischen Nehrung. Jb. Preuss. Geol. L. A., 38: 177-182.

MAKOWSKA A. (1987) - Szczegółowa mapa geologiczna Polski w skali 1:50.000, ark. Krynica Morska. Wyd. Geol.

McDERMOTT F., MATTEY D. P. and HAWKESWORTH C. (2001) Centennial-scale Holocene climate variability revealed by a high-resolution speleothem ${ }^{18} \mathrm{O}$ record from SW Ireland. Science, 294: 1328-1331.

MOE D., NIJOLE S. and STANČIKAITE M. (2005) - A new ${ }^{14} \mathrm{C}$ (AMS) date from former heathland soil horizons at Kuršiu Nerija, Lithuania. Baltica, 18 (1): 23-28.

MOJSKI J. E., DADLEZ K., SŁOWAŃSKA B., UŚCINOWICZ SZ. and ZACHOWICZ J., eds. (1995) - Geological atlas of the Southern Baltic. Państw. Inst. Geol., Sopot-Warszawa.

MOLODKOV A. and BITINAS A. (2006) - Sedimentary record and luminescence chronology of the Lateglacial and Holocene aeolian sediments in Lithuania. Boreas, 35: 244-254.
MURRAY A. S. and CLEMMENSEN L. B. (2001) - Luminescence dating of Holocene aeolian sand movement, Thy, Denmark. Quatern. Sc. Rev., 20: 751-754.

MUSIELAK S. (1980) - Współczesne procesy brzegowe w Zatoce Gdańskiej. Peribalticum, 1: 17-29.

OSADCZUK K. (2004) - Geneza i rozwój wałów piaszczystych Bramy Świny w świetle badań morfologicznych i sedymentologicznych. Uniw. Szczec., Rozpr. Stud., 552.

POREBBA G. J. and FEDOROWICZ S. (2005) - Gamma spectrometry for OSL and TL dating of loess deposits at Dybawka and Tarnawce (SE Poland). Geochronometria, 24: 27-32.

PRUSINKIEWICZ Z. and NORYŚKIEWICZ B. (1966) - Problem of age of podzols on brown dunes of bay bars of river Świna in the light of a palynological analysis and dating by radiocarbon $\mathrm{C}^{14}$ (in Polish with English summary). Zesz. Nauk. Uniw. M. Kopernika, 5: 75-88.

REIMER P. J., BAILLIE M. G. L., BARD E., BAYLISS A., WARREN BECK J., BERTRAND C., BLACKWELL P. G., BUCK C. E., BURR G., CUTLER K. B., DAMON P. E., EDWARDS R. L., FAIRBANKS R. G., FRIEDRICH M., GUILDERSON T. P., HUGHEN K. A., KROMER B., McCORMAC F. G., MANNING S., BRONK RAMSEY C., REIMER R. W., SOUTHON J. R., STUIVER M., TALAMO S., TAYLOR F. W., van der PLICHT J. and WEYHENMEYER C. E. (2004) - IntCa104 terrestrial radiocarbon age calibration. Radiocarbon, 46: 1029-1058.

REIMANN T., TSUKAMOTO S., HARFF J., OSADCZUK K. and FRECHEN M. (2011) - Reconstruction of Holocene coastal foredune progradation using luminescence dating - an example from the Świna barrier (southern Baltic Sea, NW Poland). Geomorphology, 132: 1-16.

ROTNICKI K. (2009) - Identyfikacja, wiek i przyczyny holoceńskich ingresji i regresji Bałtyku na polskim wybrzeżu środkowym. Wyd. Słowińskiego Parku Narodowego.

ROSA B. (1963) - O rozwoju morfologicznym wybrzeża Polski w świetle dawnych form brzegowych. Stud. Soc. Sc. Torunensis. Sectio C, Geograph. Geol., Torun.

ROSA B. (1987) - Pokrywa osadowa i rzeźba dna. In: Bałtyk Południowy (ed. B. Augustowski): 75-172. Ossolineum.

ROSA B. and WYPYCH K. (1980) - O mierzejach południowego Bałtyku. Peribalticum, 1: 31-44

Soil-Habitat Map of the Vistula Spit area at a scale of 1:5000, Krynica Morska sheet (in Polish). Wojewódzkie Biuro Geodezji i Urządzeń Rolnych w Gdańsku, 1969.

TOMCZAK A. (1990) - O fazach rozwoju Mierzei Wiślanej w najmłodszym holocenie w świetle dat radiowęglowych. Przewodnik LXI Zjazdu Pol. Tow. Geol. w Gdańsku, Wyd. AGH, Kraków: 104-107.

TOMCZAK A. (1995a) - Geological structure and holocene evolution of the Polish coastal zone. Prace Państw. Inst. Geol., 149: 90-102.

TOMCZAK A. (1995b) - Geological structure of the coastal zone (I, II). In: Geological Atlas of the Southern Baltic, 1:500 000 (eds. J. E. Mojski et al.). Państw. Inst. Geol., Sopot-Warszawa: Plates XXXIII, XXXIV.

TOMCZAK A., MOJSKI J. E., KRZYMIŃSKA J., MICHAŁOWSKA M., PIKIES R. and ZACHOWICZ J. (1989) - New data on geological structure of the Vistula Bay Bar (in Polish with English summary). Kwart. Geol., 33 (2): 277-300.

UŚCINOWICZ SZ. (2003) - Relative sea level changes, glacio-isostatic rebound and shoreline displacement in the Southern Baltic. Pol. Geol. Inst. Spec. Pap., 10: 1-72.

WALANUS A. and GOSLAR T. (2009) - Datowanie radiowęglowe. Wyd. AGH Kraków.

WINTLE A. G. and PRÓSZYŃSKA H. (1983) - TL dating of loess in Germany and Poland. PACT, 9: 547-554 